International Journal of Social Sciences and Humanities
Available online at www.sciencescholar.us
Vol. 4 No. 3 December 2020, pages: 168-174
e-ISSN: 2550-7001, p-ISSN: 2550-701X
http://doi.org/10.29332/ijssh.v4n3.527

\title{
Hanoman's 2D Animated Character in Ramayana Wayang Story
}

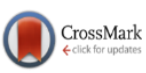

\author{
S H Heriwatia B Pujiono $^{\mathrm{b}}$, A N Panindias ${ }^{\mathrm{c}}$, Suwondo ${ }^{\mathrm{d}}$, B H Prilosadoso
}

Manuscript submitted: 09 September 2020, Manuscript revised: 18 October 2020, Accepted for publication: 27 November 2020

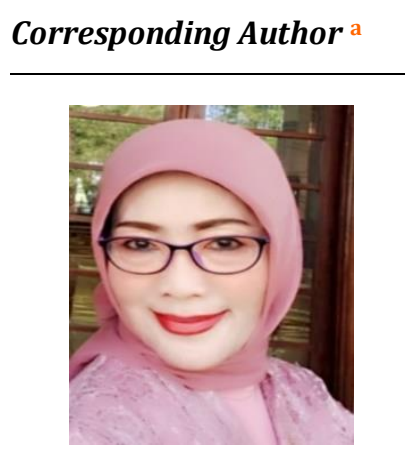

Keywords

$2 d$ animation;

education;

hanoman;

wayang ramayana;

youth segmentation;

\begin{abstract}
Research in art creation is an effort to preserve traditional arts, especially wayang kulit in the form of character development of the Hanoman character in the Ramayana story through animated 2D media which aims to introduce traditional skills among the younger generation in Surakarta. This research method of art creation uses a qualitative descriptive approach through data sources, including Ramayana puppet shows, literature studies, and competent speakers in the field of puppetry and animation. The stages of analysis from various sources of results from information from both literature reviews and interviews were carried out using an interactive model, where each component of the research includes the stages of data collection, data reduction, presentation, and conclusion drawing. Test the validity of the data using data triangulation techniques, namely triangulation of data sources and triangulation of theories. The locations of designing 2D animated Hanoman characters go through several processes, namely: the Envisioning Phase, the Planning Phase, the Design/Design Stage, the Stabilizing Phase, and the Deploying Phase. The Hanoman character in the Ramayana wayang story collaborates with 2D animation technology as an alternative to introducing wayang characters and educational media that are suitable for the younger generation segmentation.
\end{abstract}

International Journal of Social Sciences and Humanities (C) 2020. This is an open access article under the CC BY-NC-ND license (https://creativecommons.org/licenses/by-nc-nd/4.0/).

\section{Contents}

Abstract

1 Introduction.

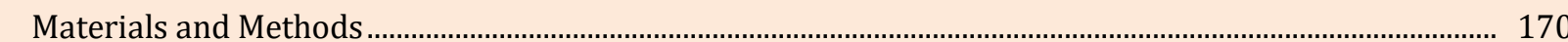

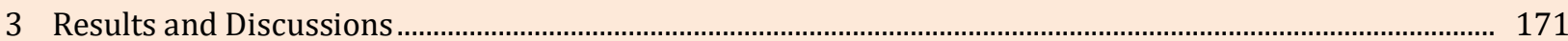

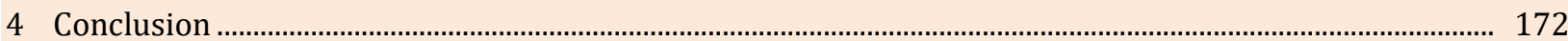

\footnotetext{
${ }^{a}$ Faculty of Art and Design, Institut Seni Indonesia (ISI) Surakarta, Indonesia

${ }^{b}$ Faculty of Art and Performing, Institut Seni Indonesia (ISI) Surakarta, Indonesia

${ }^{c}$ Faculty of Art and Design, Institut Seni Indonesia (ISI) Surakarta, Indonesia

${ }^{\mathrm{d}}$ Faculty of Art and Performing, Institut Seni Indonesia (ISI) Surakarta, Indonesia

${ }^{\mathrm{e}}$ Faculty of Art and Design, Institut Seni Indonesia (ISI) Surakarta, Indonesia
} 


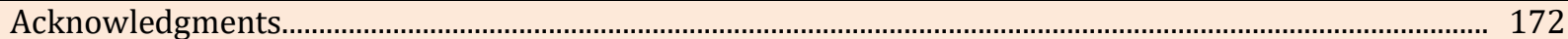

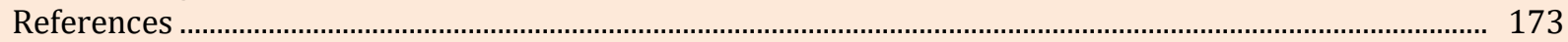

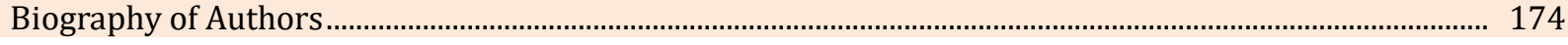

\section{Introduction}

The increasingly intense flow of globalization, where the younger generation today are still many laymen and do not know much about the meaning behind the traditional works of art that we have inherited from our ancestors, even though behind all that there are living norms that can be studied and applied in today's life. The present era is increasingly seen as the decline in moral consciousness that has been passed down from generation to generation by the ancestors has begun to be eroded by cultural influences from the west which contain influences that are more likely to be inappropriate in life in our society (Prilosadoso \& Rosmiati, 2017).

Based on the current phenomenon, in which the nation's morality is increasingly fragile, with the increasingly widespread hedonism and individualistic culture hitting the life of our society, especially among the younger generation. The decreasing awareness of moral values that have been passed down from generation to generation by our ancestors has begun to be displaced by western norms and rules which tend to be incompatible with the conditions of our society. The regional culture at this time feels critical because it has been displaced by modern culture from the west. Slowly people began to leave the local culture, which has deep meaning (Rachmadian, 2016).

The solutions to the influences experienced by our society, such as the influence of globalization, modernization, commercialization, and the development of communication technology that have penetrated the world have an impact on the existence of traditional cultural arts which tend to reduce the existence of art from our ancestral heritage (Pujiono et al., 2020). Through the development of an increasingly globalized world, capable of displaying resilience and the ability to anticipate the development of the era, wayang kulit has succeeded in achieving high artistic quality. The durability and development of these puppets can face the journey from time to time by always maintaining the content of local wisdom that accompanies wayang journeys at all times. According to Pietrobruno (2009), high-quality art can be performed with wayang kulit, where the development of the shadow puppet world can survive in the modern era. Therefore, the form of world recognition of wayang that was handed over by the Indonesian government to UNESCO is to protect the existence of world culture by prioritizing the convention of safeguarding cultural heritage safely (Prilosadoso et al., 2020) The current condition the existence of the traditional wayang art is still one of the things that are synonymous with the culture that grows in every region. A puppet show contains many aspects including sound arts, literary arts, music arts, speech arts, fine arts, and other arts (Putri et al., 2019).

Wayang Indonesia on 7 November 2003 has been named by UNESCO, that as a Masterpiece of the Oral and Intangible Heritage of Humanity, or a Cultural Master peace of the World. The World recognizes wayang as a masterpiece of non-material world culture. This determination is momentum to raise awareness among various groups of culture as well as the strength of the nation, thereby enhancing Indonesia's image in international eyes. Wayang content contains much content about character education, which is a transformation of the values of life in a person's personality so that they become one in the behavior of people's lives in the community (Sutedjo \& Prilosadoso, 2016). Besides, it is hoped that the puppet will get a positive response and be of interest to the community, especially the younger generation (Ahmadi et al., 2019).

The animation is one of the sub-sectors of the creative industry, which includes businesses whose current business opportunities are up-and-coming and able to absorb a large number of creative workers. The animation industry is not only targeting children but also teenagers and adults. The choice of 2D animation media for Hanoman's character in the Ramayana story is tailored to the character of the younger generation as the successor and preserver of this shadow puppet art, where the new generation is a generation that upholds the quality of life in the future (Durand, 1991; Farahani et al., 2020). The backbone of a nation's future and as a generator for most technological advances. Whenever a new technology comes in, they are the first to try it and consume it.

Heriwati, S. H. ., Pujiono, B. ., Panindias, A. N. ., Suwondo, S., \& Prilosadoso, B. H. . (2020). Hanoman's $2 D$ animated character in ramayana wayang story. International Journal of Social Sciences and Humanities, 4(3), 168-174. https://doi.org/10.29332/ijssh.v4n3.527 
Based on the introduction above, this design will try to develop as a solution in the form of Hanoman character design with 2D-dimensional animation applications that can be used as a medium for delivering information and are useful but easy to access and fun, supported by multimedia (voice text, images, animation, video) interactive. The animation is a visualization technique that is widely used in the world of film today, either as a complete unit, part of live-action or as one with live-action (Lee et al., 2019). The world of film has its roots in the world of photography, while animation has its roots in the world of images, namely illustration and graphic design. 2D animation is excellent if it is used in a learning media and recognition in the form of two-dimensional or three-dimensional objects, such as wayang kulit stories that require visualization from the user, besides 2D-dimensional animation can combine virtual objects into a real environment that can be displayed realtime which will attract understanding for the segmentation of young people, and get to know the meaning contained in it.

\section{Materials and Methods}

This research will specifically design a 2dimensional animation work from the form of shadow puppets so that it is expected to be able to attract the audience, especially the generation of millennials, through a qualitative descriptive research approach to producing works that will answer the research. According to Sutopo (2003), the reason is that this method (1) can describe the process from time to time in a natural situation without the researcher's engineering; (2) allows for inductive analysis, which is oriented towards exploration, discovery, and inductive logic, so that the resulting theory is based on patterns in reality; and (3) enable the description of human behavior in a natural context (Nugrahani, 2012). The method used is through qualitative research methods using a questionnaire which aims to learn details about the subject under study (Turan, 2014). In the implementation of this research, it is included in descriptive qualitative research that focuses on describing and explaining the role of information technology, especially in the 2D animation field as a solution and alternative for the development of shadow puppets in the modern era, especially the Hanoman character in the Ramayana story for young audiences. Research on this culture will reveal how an intangible heritage of the world includes practices that forge traditions and commodification and eliminate boundaries between countries in this world (Pietrobruno, 2009).

This research aims to develop 2-dimensional animation media of Hanoman's character from the Ramayana wayang story through various media, one of which is the animation which aims to preserve shadow puppets in Surakarta for the younger generation. In this research, the method used in this research was developed by formulating principles in animation literature (Kwon \& Lee, 2011). Technology innovation is the main driving factor for success in winning a competition at the global level as in the current era. Technological innovation can be positioned as the central development of national development. The presence of this information media causes the communication process to have a different style and appearance for each information and the target audience to be targeted (Guizar \& Panindias, 2019). The process of analysis of various sources of results from information both from the literature review and interviews is conducted using an interactive model, where each component of the analysis includes the stages of data collection, data reduction, presentation, and conclusion drawing. The mechanism of the analysis process according to Miles \& Huberman (1994) will be carried out in a continuous direction as the cycles interact with each other until the information sought is genuinely complete. In this study, the primary data sources were the Hanoman characters and the 2-dimensional animation design.

A general explanation, based on the production tools provided to produce an expository animated video, follow the steps as follows.

a) Pick a character. The user can customize and match each character with features such as a potbelly, cat glasses, hairstyles, or gorilla hands;

b) Pick a background. Animasher's options include halls, market locations, and swimming pools;

c) Add dialogue. The user can add or enter in the dialogue and select accents. Production tools can produce suitable synthesized sounds, such as offering sound effects such as fireworks and screams as background sound;

d) Direct. Users can edit the scene layout, for example, to add pauses, movement, layout in camera angle, even crop and zoom in and out (Xiao, 2013). 
Test the validity of the data by using data triangulation techniques, namely data source triangulation and theory triangulation. Data triangulation is used to check the validity of data by using other things. Data analysis techniques use interactive chain analysis with steps including data collection, data reduction, data presentation, and conclusion drawing.

\section{Results and Discussions}

\section{Local Wisdom Content as Character Education Media in Wayang Kulit}

The origin of the word Purwa comes from Sanskrit which has the meaning of first, previous, or first. While other meanings, the word Purwa means ancient, and wayang kulit purwa can mean ancient times. Wayang kulit purwa is estimated to have the oldest age among other types of wayang. The purwa leather puppets themselves consist of various styles, types, or other words, namely gagrak, among others; gagrak Surakarta, gagrak Ngayogyakarta, gagrak Banyumas, etc. (Kurnianto \& Limano, 2016). The history of wayang art before the beautiful engraved stone materials inscribed in the reliefs of Borobudur and Prambanan Temples have become myths, stories, or images that have existed for hundreds of years before. The masters of wayang creators in Java could wisely accept the influence of Islamic teachings that prohibited realistic drawing, so that the puppets turned into very stylistic, stylized human compositions, so they were called Wayang Purwa (kawitan, beginning). The appearance of wayang kulit both from the characterization and story aspects will contain a high philosophical aspect. The values of wayang stories can become a reflection of the identity and character development of a nation (Robinson \& Sexton, 1994; Psacharopoulos, 1994). Character is the identity, personality, and character that is inherent in a person related to the psychological and physical dimensions. The content in the puppet contains character education as a transformation of the norms and values of life in one's personality so that it becomes one in the behavior of people's lives in the surrounding environment (Sutedjo \& Prilosadoso, 2016).

As a form of performing arts that is very popular and favored by various levels of society, the traditional art of wayang kulit in Java, especially in Central Java and East Java, apart from the popularity of wayang kulit, it is also the only type of wayang in Java that has survived until now. Wayang is a form of performing art that involves art actors (artists), accompanists, art express media, performance space, performance time, and the audience (connoisseurs/audience) also uses a flat form (wayang kulit) as the primary medium in which it contains elements of play and functional elements include language, sound, appearance, and motion. The visual aspect can be observed through wayang figures. Movement can be observed through the alphabet, which is all puppet movements in performance. The performance of the four elements of pakeliran supports and complements each other so that it becomes a harmonious performance unit.

\section{Animation Media as a Character Design for Hanoman}

The story from the Ramayana in which there is a Hanoman figure, which in the story of the puppet show contains many stories that are role models, role models, and loyalty. The character of the Hanoman knight in the Ramayana story of the play Hanoman Duta is a reflection of state servants who carry out their duties by adhering to the value of loyalty. Hanoman as Sri Rama Wijaya's envoy to find Dewi Sinta who was kidnapped by King Alengka, namely Rahwana. Hanoman character design may include characters categorized as "imaginary", legend or myth. This understanding is experienced in the present, where the products of the world of information technology are very dominant. The process of designing an illustration character animation 2dimensional will involve many ideas and ideas to determine the elements of the story, characters, settings, and backgrounds (Prilosadoso et al., 2019).

The image of a profile, in general, is initially identified from its visual elements. The facial or gesture expression characteristics of a profile have a meaning that is constructed based on the visual culture of the audience or the communicant who interacts with the character's profile. The content of animation that is most commonly known in the community today uses much technology based on Flash or Java. From an animation

Heriwati, S. H. ., Pujiono, B. ., Panindias, A. N. ., Suwondo, S., \& Prilosadoso, B. H. . (2020). Hanoman's $2 D$ animated character in ramayana wayang story. International Journal of Social Sciences and Humanities, 4(3), 168-174. https://doi.org/10.29332/ijssh.v4n3.527 
application perspective, there is more room in educational media compared to educational approaches from other media (Xiao, 2013) The stages of designing Hanoman's character can be explained as follows as contained in the book Art Consortium (1986) which includes five processes according to Bandem (2005), namely: (a) observation, (b) collaboration and elaboration, (c) analysis and synthesis,(d) realization, and (e) project finalization. This character design method is expected to make the Hanoman figure more familiar and familiar so that the youth segment can accept the puppet characters.

\section{Conclusion}

The character development of the puppet character in the form of Hanoman which is taken from one of the Ramayana stories can be explained that from the identification results of Hanoman it shows that the figure can collaborate into a 2D animation media show that is following the character and segmentation in this study, namely the younger generation. Through the 2-dimensional animation design stages, namely (a) observation, (b) collaboration and elaboration, (c) analysis and synthesis, (d) realization, and (e) project finalization, Hanoman's character is tough, has a spirit of heroism, and also has a healthy attitude. Kind and polite. The results of the research in the form of 2D animated characters, Hanoman's character dimensions are aimed at increasing interest and enthusiasm among the younger generation for traditional arts, especially wayang kulit.

The role of various stakeholders, such as the community, government, and academia, to always work together to create an effort to preserve and develop traditional art. Development with collaboration between traditional arts and technology is still wide open to create alternative art developments so that the ancestral heritage is sustainable and not also lost his identity.

\section{Acknowledgments}

The process of compiling this research until the final stage of writing this article, the research team is very grateful to all those who have supported the implementation from beginning to end. The author would like to thank the Directorate of Research and Community Service of the Ministry of Research and Higher Education who has funded this research and the Indonesian Institute of the Arts (ISI) Surakarta as well as various parties who have supported and helped until the completion of this research stage. 


\section{References}

Ahmadi, A., Sumadi, S., Murfianti, F., \& Murwanti, S. (2019, April). The Creation Of Pattern Of Main Characters Of Wayang Beber For Designing Of The Icon Of Pacitan As City Of Tourism. In Proceeding of International Conference on Art, Language, and Culture (pp. 9-16).

Bandem, I. M. (2005). Kekhasan Penelitian Bidang Seni. Jurnal Ekspresi. Institut Seni Indo-nesia Yogyakarta, 15.

Durand, C. X. (1991). The "TOON" project: requirements for a computerized 2D animation system. Computers \& graphics, 15(2), 285-293. https://doi.org/10.1016/0097-8493(91)90081-R

Farahani, J., Soltani, P., Rezlescu, C., \& Walsh, V. (2020). Assessing decision making using 2D animations in elite academy footballers. In Progress in Brain Research (Vol. 253, pp. 71-85). Elsevier. https://doi.org/10.1016/bs.pbr.2020.06.016

Guizar, V. T., \& Panindias, A. N. (2019). Media Promosi Edukasi Sejarah Melalui Perancangan Karakter Visual Singo Ulung Bondowoso. TEXTURE: Art \& Culture Journal, 2(1), 74-83.

Kurnianto, A., \& Limano, F. (2016, December). Visual representation of character of wayang kulit purwa in the wayang-based games: Case studies of Kurusetra and Mahabarat warrior games. In 2016 1st International Conference on Game, Game Art, and Gamification (ICGGAG) (pp. 1-6). IEEE.

Kwon, J. Y., \& Lee, I. K. (2011). Cartoon-like stylization for character animation. In 2011 International Symposium on Ubiquitous Virtual Reality (pp. 48-51). IEEE.

Lee, Y. O., Curry, L. E., Fiacco, L., Henes, A., Farrelly, M. C., Nonnemaker, J. M., ... \& Walker, M. W. (2019). Peer crowd segmentation for targeting public education campaigns: Hip hop youth and tobacco use. Preventive medicine reports, 14, 100843. https://doi.org/10.1016/j.pmedr.2019.100843

Miles, M. B., \& Huberman, A. M. (1994). Qualitative data analysis: An expanded sourcebook. sage.

Nugrahani, F. (2012). Reaktualisasi tembang dolanan Jawa dalam rangka pembentukan karakter bangsa (kajian semiotik).

Pietrobruno, S. (2009). Cultural research and intangible heritage. Culture Unbound: Journal of Current Cultural Research, 1(1), 227-247.

Prilosadoso, B. H., \& Rosmiati, A. (2017). Identitas Visual Desa Wisata Batik Cokrokembang Melalui Environment Graphic Design Sebagai Pengembangan Di Kabupaten Pacitan. Acintya Jurnal Penelitian Seni Budaya, 9(1).

Prilosadoso, B. H., Pujiono, B., \& Supeni, S. (2020). The Character of the Pacitan Wayang Beber Cartoon as a Cultural Preservation Effortfor Millennial's Generation. International Journal of Advanced Science and Technology, 29(4), 2517-2522.

Prilosadoso, B. H., Pujiono, B., Supeni, S., \& Setyawan, B. W. (2019). Wayang beber animation media as an effort for preserving wayang tradition based on information and technology. In Journal of Physics: Conference Series (Vol. 1339, No. 1, p. 012109). IOP Publishing.

Psacharopoulos, G. (1994). Returns to investment in education: A global update. World development, 22(9), 1325-1343. https://doi.org/10.1016/0305-750X(94)90007-8

Pujiono, B., Prilosadoso, B. H., \& Supeni, S. (2020). Alternative Media for the Preservation of Traditional arts Through Collaboration Pop art Style Wayang Pacitan Beber. International Journal of Social Sciences and Humanities, 4(3), 151-159. https://doi.org/doi.org/10.29332/ijssh.v4n3.490 Alternative

Putri, R. O. C. E., Firdausi, N. A., Susetya, B. A., \& Prilosadoso, B. H. (2019). Pelestarian Cerita Ramayana Melalui Media Wayang Limbah Kertas Untuk Siswa Sekolah Dasar Di Sukoharjo. Prosiding: Seni, Teknologi, Dan Masyarakat, 2, 245-251.

Rachmadian, A. (2016). Pengaruh Masuknya Budaya Asing Terhadap Pelestarian Kebudayaan Tari Tradisional Wayang Topeng Malangan Di Malang Raya, Jawa Timur. Jurnal Pariwisata Pesona, 1(2).

Robinson, P. B., \& Sexton, E. A. (1994). The effect of education and experience on self-employment success. Journal of business Venturing, 9(2), 141-156. https://doi.org/10.1016/0883-9026(94)90006-X

Sutedjo, A., \& Prilosadoso, B. H. (2016). Perancangan Desain Permainan Materi Pendidikan Anak Usia Dini Berbasis Wayang Beber. Acintya Jurnal Penelitian Seni Budaya, 8(1).

Sutopo, A. H. (2003). Multimedia interaktif dengan flash. Yogyakarta: Graha Ilmu, 32-48.

Turan, B. (2014). The opinions of teachers on the use of cartoon character in the mathematics lesson. ProcediaSocial and Behavioral Sciences, 141, 1386-1391. https://doi.org/10.1016/j.sbspro.2014.05.239

Xiao, L. (2013). Animation trends in education. International Journal of Information and Education Technology, 3(3), 286.

Heriwati, S. H. ., Pujiono, B. ., Panindias, A. N. ., Suwondo, S., \& Prilosadoso, B. H. . (2020). Hanoman's $2 D$ animated character in ramayana wayang story. International Journal of Social Sciences and Humanities, 4(3), 168-174. https://doi.org/10.29332/ijssh.v4n3.527 


\section{Biography of Authors}

\begin{tabular}{|c|c|}
\hline 5 & $\begin{array}{l}\text { Dr. Sri Hesti Heriwati, M. Hum. Graduated with a Doctorate from the Sebelas Maret } \\
\text { University of Surakarta in } 2014 \text {. Now as a lecturer at the ISI, the solo is a general lecture in } \\
\text { Indonesian language and literature. Currently implementing applied research funded by the } \\
\text { second year Kementerian Riset dan Pendidikan Tinggi. } \\
\text { Email: hesti_hawe@yahoo.com }\end{array}$ \\
\hline & $\begin{array}{l}\text { Dr. Bagong Pujiono, S.Sn., M.Sn originally in Kebumen, Central Java, 1980. Doctorate from } \\
\text { the Indonesian Institute of the Arts, Surakarta, 2015. Apart from being an art player or } \\
\text { puppeteer, he also serves as a teacher and researcher at the Puppetry Arts Department. } \\
\text { There are many manuscripts for shadow puppet and golek performances, including Sang } \\
\text { Urubisma, Sri Tanjung, Babad Majapahit, Kewlidheng, Makhutarama, Tripama, and many } \\
\text { more. Writing works in the form of publications, and paperwork including the aesthetics of } \\
\text { Wayang Golek Kebumen, Variety of Wayang Golek Kebumen, Animated Wayang Beber, } \\
\text { Theater Catur in Tradition, Wayang Gedhog, Wayang Rare, and many others. } \\
\text { Email: bagong_puji@yahoo.com }\end{array}$ \\
\hline & $\begin{array}{l}\text { Basnendar Herry Prilosadoso, S.Sn., M.Ds, as a lecturer in the Visual Communication Design } \\
\text { Study Program, Faculty of Art and Design, Indonesian Art Institute (ISI), Surakarta, now } \\
\text { taking the Post-Graduate Doctoral Program in Art Assessment, Indonesian Art Institute } \\
\text { (ISI), Surakarta, besides doing a lot of research on the fields of art and design, as } \\
\text { cartoonists, and graphic design freelancers. Several times participated in exhibiting art and } \\
\text { design both at national and international levels. } \\
\text { Email: basnendart@yahoo.com }\end{array}$ \\
\hline & $\begin{array}{l}\text { Suwondo, S.Kar., M.Hum. born in Tulungagung, on Mey 25, 1958. Obtained a master's } \\
\text { degree in art from the Performing Arts and Fine Arts Study from the Postgraduate Program } \\
\text { of Gadjah Mada University in Yogyakarta. As a lecturer in the Pedalangan Study Program, } \\
\text { Faculty of Performing Arts, Indonesian ArtInstitute (ISI), Surakarta. Some manuscripts and } \\
\text { wayang kulit performances, including Lakon Kumbo Karno Guru, Lakon Partadewa, Lakon } \\
\text { Kresna Kembang, and so on. } \\
\text { Email: suwondo@isi-ska.ac.id }\end{array}$ \\
\hline & $\begin{array}{l}\text { Asmoro Nurhadi Panindias, S.Sn., M.Sn, as a lecturer in the Visual Communication Design } \\
\text { Study Program, Faculty of Art and Design, Indonesian Art Institute (ISI), Surakarta. Highly } \\
\text { capable professional in graphic design with a focus on visual identity and multimedia } \\
\text { interactive, also many studies in the fields of art and design creativity. Experienced teacher } \\
\text { and facilitator with } 14 \text { years of service. } \\
\text { Email:asmoro@isi-ska.ac.id }\end{array}$ \\
\hline
\end{tabular}

